OPEN ACCESS

Edited by:

Paula Alvarenga

Instituto Superior de Agronomia (ISA),

Portugal

Reviewed by:

Arturo F. Chica,

Universidad de Córdoba, Spain

M. Ángeles Gómez-Sánchez,

Universidad de Salamanca, Spain

*Correspondence:

Diego C. Zied

dczied@gmail.com

Specialty section: This article was submitted to

Waste Management in

Agroecosystems,

a section of the journal

Frontiers in Sustainable Food Systems

Received: 23 March 2018

Accepted: 31 May 2018

Published: 22 June 2018

Citation:

Zied DC, Caitano CEC

Pardo-Gimenez A, Dias ES, Zeraik ML and Pardo JE (2018) Using of Appropriated Strains in the Practice of Compost Supplementation for

Agaricus subrufescens Production.

Front. Sustain. Food Syst. 2:26

doi: 10.3389/fsufs. 2018.00026

\section{Using of Appropriated Strains in the Practice of Compost Supplementation for Agaricus subrufescens Production}

\author{
Diego C. Zied ${ }^{1 *}$, Cinthia E. C. Caitano ${ }^{1}$, Arturo Pardo-Gimenez ${ }^{2}$, Eustáquio S. Dias ${ }^{3}$, \\ Maria L. Zeraik ${ }^{4}$ and Jose E. Pardo ${ }^{5}$ \\ ${ }^{1}$ Faculdade de Ciências Agrárias e Tecnológicas, Universidade Estadual Paulista, Dracena, Brazil, ${ }^{2}$ Centro de Investigación, \\ Experimentación y Servicios del Champiñón, Quintanar del Rey, Spain, ${ }^{3}$ Departamento de Biologia, Universidade Federal de \\ Lavras, Lavras, Brazil, ${ }^{4}$ Departamento de Química, Universidade Estadual de Londrina, Londrina, Brazil, ${ }^{5}$ Escuela Técnica \\ Superior de Ingenieros Agrónomos y de Montes, Universidad de Castilla-La Mancha, Albacete, Spain
}

The aim of this study was to analyse the viability of supplementation of Agaricus subrufescens compost with different organic materials, using three commercial strains. Compost was prepared by the traditional method and was used as a control (without supplementation). Six supplements were applied and can be separated into four categories: (i) commercial supplements (recommended to Agaricus bisporus and Pleurotus ostreatus); (ii) supplements based on agro-industrial waste (provided by peanut and acerola juice); (iii) supplements based on noble grains (a mix with bran of soybean, corn, and cotton); and (iv) a blend of supplements (ii) and (iii) (peanut waste, acerola juice waste, and noble grains - a mixture of $33.3 \%$ each). The results showed that the practice of supplementation is an important tool to improve the yield in the industrial production of $A$. subrufescens. Waste materials and noble grains can be selected as quality supplements. The use of appropriated strains is essential for the success of the supplementation practice.

Keywords: Agaricus blazei, bioconversion, medicinal mushroom, sun mushroom, waste materials, yield

\section{INTRODUCTION}

An emerging Agaricus species, Agaricus subrufescens Peck, also named Agaricus blazei Murrill sensu Heinemann, Agaricus rufotegulis Nauta, or Agaricus brasiliensis Wasser, M. Didukh, Amazonas \& Stamets, has been an actively cultivated mushroom in Brazil since 90's; when it was cultivated for first time in the Sao Paulo State and then extended to other regions close to the Atlantic coast (Farnet et al., 2014).

This ascend is because of the important medicinal proprieties of the mushrooms used for the treatment of cancer, leukemia, and hypertension, which are attributed to its active compounds, such as glycoproteins, $\beta$-d-glucans, saponins, steroids, tannins, polysaccharides, ergosterol, and fatty acids (Wang H. et al., 2013; Venkateshgobi et al., 2018). Previous studies reported that aqueous extracts of $A$. blazei offered the neuroprotective effect against the experimental model of Parkinson's disease and aging due to its anti-oxidant, anti-inflammatory, and anti-apoptotic functions (Nakanishi et al., 2014; Venkatesh Gobi et al., 2017, 2018). 
During the last 5 years, various studies occurred involving several steps of production, with the objective of making commercial production more and more feasible, transforming family scale units to industrial scale production (Dias et al., 2013; Llarena-Hernández et al., 2014; Pardo-Giménez et al., 2014; Zied et al., 2014a; Carvalho Sousa et al., 2016).

Among the different steps of production, compost (formulation, phase I and II) is thought to be one of the most important, because it directly influences the productivity and quality of the mushrooms (Horm and Ohga, 2008; Matute et al., 2010; Llarena-Hernández et al., 2013; Wang J. T. et al., 2013; Souza et al., 2014). To improve the compost process, substrate supplementation has been used to provide nutrients to the developing mushroom, reducing the cultivation cycle and increasing productivity by up to $30 \%$ (Pardo-Giménez et al., 2012, 2016).

The practice of supplementation can be carried out at spawning, which does not demand additional production costs, except purchasing supplements that will be added to substrate. Currently, several companies commercialize supplements to be applied in the cultivation of Agaricus bisporus and Pleurotus ostreatus, although commercial supplement was not found for industrial scale of $A$. subrufescens production.

Therefore, the aim of this study was to analyse the efficiency of supplementation in A. subrufescens compost at spawning, with different sources of organic materials, using three commercial strains. In addition, this study considered the influence of the chemical characteristics of the supplements on the physiological development of the mushrooms.

\section{MATERIALS AND METHODS}

\section{Strains}

Three commercial strains were used, including ABL 16/01 and ABL 16/02 (provided by the company Funghi \& Flora, Valinhos, Brazil) used by growers in Sao Paulo State and ABL 16/03 (codified as CS7-Carvalho Sousa et al., 2016) used by growers in Minas Gerais State. The strains are deposited in the public culture collection of Sao Paulo State University, Câmpus de Dracena (FCAT/UNESP), which allows access to interested researchers. Spawns of each strain were produced on sterile sorghum-based substrate (Sorghum bicolor) supplemented with gypsum $\left(160 \mathrm{~g} \mathrm{~kg}^{-1}\right)$ and lime $\left(20 \mathrm{~g} \mathrm{~kg}^{-1}\right)$. All preparation and sterilization procedures were done in accordance with Zied et al. (2010, 2014b).

\section{Compost}

The compost was prepared using the traditional method, lasting 22 days of phase I and 10 days of phase II, totalling 32 days. The formulation used had a dry weight of $1,000 \mathrm{~kg}$ of Panicum maximum, $1,500 \mathrm{~kg}$ of sugarcane bagasse, $50 \mathrm{~kg}$ of soybean, $5 \mathrm{~kg}$ of urea, $5 \mathrm{~kg}$ of ammonium sulfate, $10 \mathrm{~kg}$ of superphosphate, and $40 \mathrm{~kg}$ of limestone. The bulk materials ( $P$. maximum straw and sugar cane bagasse) were moistened for 9 days and rotated after 2 days. The concentrated materials (soybean, urea, ammonium sulfate, simple superphosphate, and lime) were added after each turning operation throughout the composting phase I (Table 1).
The compost remained for $18 \mathrm{~h}$ at $59 \pm 1^{\circ} \mathrm{C}$ for pasteurization and 8 days at $47 \pm 2{ }^{\circ} \mathrm{C}$ for conditioning during phase II of composting. The chemical characteristics of the compost at the end of phase II are listed in Table $\mathbf{1 .}$

\section{Supplement}

Six supplements were used in the research and can be separated into four categories: (i) commercial supplements (Spawn Mate II SE ${ }^{\circledR}$-recommended to the production of $P$. ostreatus and Pro Mycel Gold ${ }^{\circledR}$-recommended to the production of $A$. bisporus, both of Amycel and Spawn Mate company, Watsonville, US); (ii) supplements based on agro-industrial wastes (20\% grain or nut and $80 \%$ hulls provided of peanut waste and acerola waste-special seeds, obtained after the extraction of the juice); (iii) supplement-based noble grains (bran of soybean, corn, and cotton-a mixture of $33.3 \%$ each); and (iv) a mix of supplements (ii) and (iii) (peanut waste, acerola juice waste, and noble grains-a mixture of $33.3 \%$ each), which was used in order to provide a balance of the chemical characteristics of the three supplements presented in category (ii) and (iii). Supplements (ii), (iii), and (iv) were dried at $68^{\circ} \mathrm{C}$ for $24 \mathrm{~h}$ (which served as a heat treatment) until reaching $4-6 \%$ moisture and then were crushed with a $<0.5 \mathrm{~mm}$ sieve. Additionally, a substrate without supplement was used as a control. The chemical characteristics of each supplement used are listed in Table 2. The macro and micro nutrient content, organic matter $(\mathrm{OM}), \mathrm{C} / \mathrm{N}$ ratio, and $\mathrm{pH}$ were evaluated following the methodology presented by Bell and Ward (1984) and Sonneveld and van Elderen (1994).

\section{Supplementation at Spawning}

At spawning or at the end of the Phase II composting process, supplements were added to the compost in the amount of $1 \%$ wet weight of compost. At the same time, the strains were added to the compost in the amount of $1.5 \%$ of spawn wet weight of compost. Therefore, in each bag, we deposited $4 \mathrm{~kg}$ of compost with $40 \mathrm{~g}$ of supplement and $60 \mathrm{~g}$ of spawn. Spawn run occurred under controlled temperature $\left(26^{\circ} \mathrm{C}\right)$, relative humidity $(80 \%)$ and carbon dioxide content $(3,000 \mathrm{ppm})$ conditions and was delayed 18 days.

\section{Casing Layer}

Soil with $350 \mathrm{~g} \mathrm{~kg}^{-1}$ of clay, $100 \mathrm{~g} \mathrm{~kg}^{-1}$ of silt, and $550 \mathrm{~g} \mathrm{~kg}^{-1}$ of sand was collected $2.0 \mathrm{~m}$ below surface, as recommended by Zied et al. (2011a), to produce A. subrufescens casing layer. Calcitic lime was added to the soil for $\mathrm{pH}$ correction as well as small fragments of charcoal in the proportion of $4: 1(\mathrm{v} / \mathrm{v})$ to increase the porosity and reduce the density and compaction of the casing layer. When the mycelia were fully developed, the compost was pressed, and leveled to facilitate the addition of the casing layer to a height of $5 \mathrm{~cm}$.

\section{Production}

The total production phase after casing addition was 90 days, with four flushes of mushroom harvested. The first one lasted 12 days, the second lasted 6 days, the third lasted 4 days, and finally, the fourth lasted 3 days. During the production, the air 
TABLE 1 | Operations performed during the composting process (phase I) and chemical analysis of compost at the end of phase II.

\begin{tabular}{|c|c|}
\hline Day & Procedures \\
\hline 01 & Wetting of the straw and sugar cane bagasse (cord mounting) \\
\hline 04 & 1st turning of the compost and addition water \\
\hline 07 & 2nd turning of the compost and addition water \\
\hline 10 & 3rd turning and addition of soybean and water \\
\hline 13 & 4th turning and addition of urea, ammonium sulfate and simple superphosphate \\
\hline 16 & 5th turning and addition of lime and water \\
\hline 19 & 6th turning and addition of water \\
\hline 22 & Filling the pasteurization tunnel (phase II) \\
\hline 32 & Spawning and addition of supplements \\
\hline
\end{tabular}

Chemical characteristics of the compost

\begin{tabular}{|c|c|c|c|c|c|c|c|c|c|c|c|c|c|}
\hline $\mathbf{N}$ & $\mathbf{P}$ & $\mathbf{K}$ & $\mathrm{Ca}$ & Mg & $\mathbf{S}$ & B & $\mathrm{Cu}$ & $\mathrm{Fe}$ & Mn & $\mathrm{Zn}$ & OM & $\mathrm{C} / \mathrm{N}$ & $\mathrm{pH}$ \\
\hline \multicolumn{6}{|c|}{$\mathrm{g} \mathrm{kg}^{-1}$} & \multicolumn{5}{|c|}{$\mathrm{mg} \mathrm{kg}^{-1}$} & $\%$ & ratio & \\
\hline $15 \pm 0.7$ & $2.9 \pm 0.2$ & $9 \pm 0.6$ & $50 \pm 3.6$ & $2.1 \pm 0.4$ & $6.4 \pm 0.5$ & $20 \pm 3$ & $17 \pm 1.2$ & $7456 \pm 17$ & $141 \pm 4,9$ & $107 \pm 9$ & $53 \pm 2$ & $21 \pm 1 / 7$ & $6.1 \pm 0.4$ \\
\hline
\end{tabular}

Each value is expressed as mean \pm standard deviation $(n=3)$.

TABLE 2 | Chemical characteristics of the supplements.

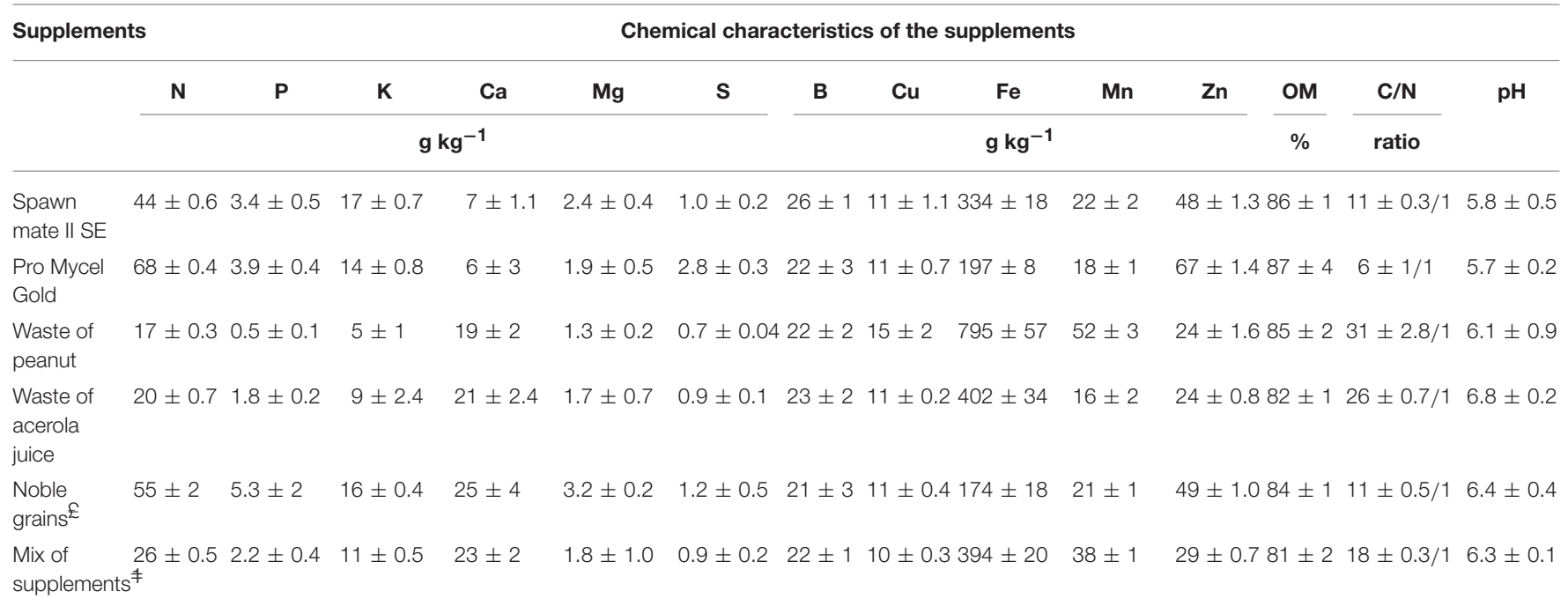

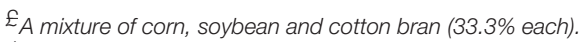

${ }^{7}$ A combination of waste of peanut, waste of Acerola juice, and a mixture of noble grains (33.3\% each). Each value is expressed as mean \pm standard deviation ( $\left.n=3\right)$.

temperature ranged from 18 to $30^{\circ} \mathrm{C}$, the compost temperature ranged from 20 to $28^{\circ} \mathrm{C}$, and the relative humidity was between 85 and $90 \%$. For primordial induction, the temperature was reduced to $2^{\circ} \mathrm{C}$ per day until reaching $20^{\circ} \mathrm{C}$ following the methodology presented by Zied and Minhoni (2009). The basidiocarps were harvested manually, followed by scraping the base of the stipe to remove the casing layer residues. The analysis was subsequently performed to quantify (i) the yield calculated as 100 times the wet weight of the mushrooms divided by the wet weight of compost, expressed as a percentage (1st, 2nd, 3rd, and 4th flush and total yield); (ii) the number of mushrooms harvested; and (iii) the weight per mushroom, expressed in grams (total fresh weight harvested during the cycle) divided by the number of mushrooms by bag, as previously described by Zied et al. (2014b), Pardo-Giménez et al. (2016), and Zied et al. (2017).

\section{Statistical Analyses}

The experiment was carried out using a double factorial, completely randomized design, with seven supplementations (six supplements + control $) \times$ three strains, totalling 21 treatments, each with six replicates (represented by a box containing $4 \mathrm{~kg}$ of wet compost). The variations between the chemical compositions of the supplements were analyzed considering the similarity by using the Nearest Neighbor Method. The means of each variable were compared by the least significant difference (LSD) test at 
$p<0.05$ using SAS JMP software. Sigma Stat 3.5 software was used to calculate the linear correlations among the values for the yield (1st, 2nd, 3rd, 4th, and total), number, and weight of the basidiocarps and the chemical characteristics of the supplements.

\section{RESULTS}

The supplements formulated in this study had the highest $\mathrm{Ca}$ values. Commercial supplements (Spawn Mate and Pro Mycel Gold) and noble grains showed the highest values of $\mathrm{N}, \mathrm{P}, \mathrm{K}, \mathrm{Mg}$, $\mathrm{S}$, and $\mathrm{Zn}$ and, in this sense, are characterized as supplements with high nutritional content (Table 2). According to Figure 1, the macronutrient and micronutrient contents, $\mathrm{OM}, \mathrm{C} / \mathrm{N}$ ratio, and $\mathrm{pH}$-values of the commercial supplements were considered similar, by using the Nearest Neighbor Method.

Supplements from the peanut and acerola juice waste showed the highest values of $\mathrm{Fe}$ and $\mathrm{C} / \mathrm{N}$ ratio, and the peanut waste showed high $\mathrm{Cu}$ and $\mathrm{Mn}$ contents. The mix of supplements $(33.3 \%$ peanut waste $+33.3 \%$ acerola juice waste $+33.3 \%$ noble grains) showed intermediate results, which were similar to the supplement formulated with the acerola juice waste, which had the highest proximity resulting in inferior distance in the Nearest Neighbor Method. The peanut waste supplement showed superior distance to the other supplements being the most different supplement from the chemical point of view when compared to the other supplements (Figure 1).

As the evaluation of the yield in the flushes were separately done, ABL 16/01 strain presented the highest results when the supplements were added, which can be checked comparing the

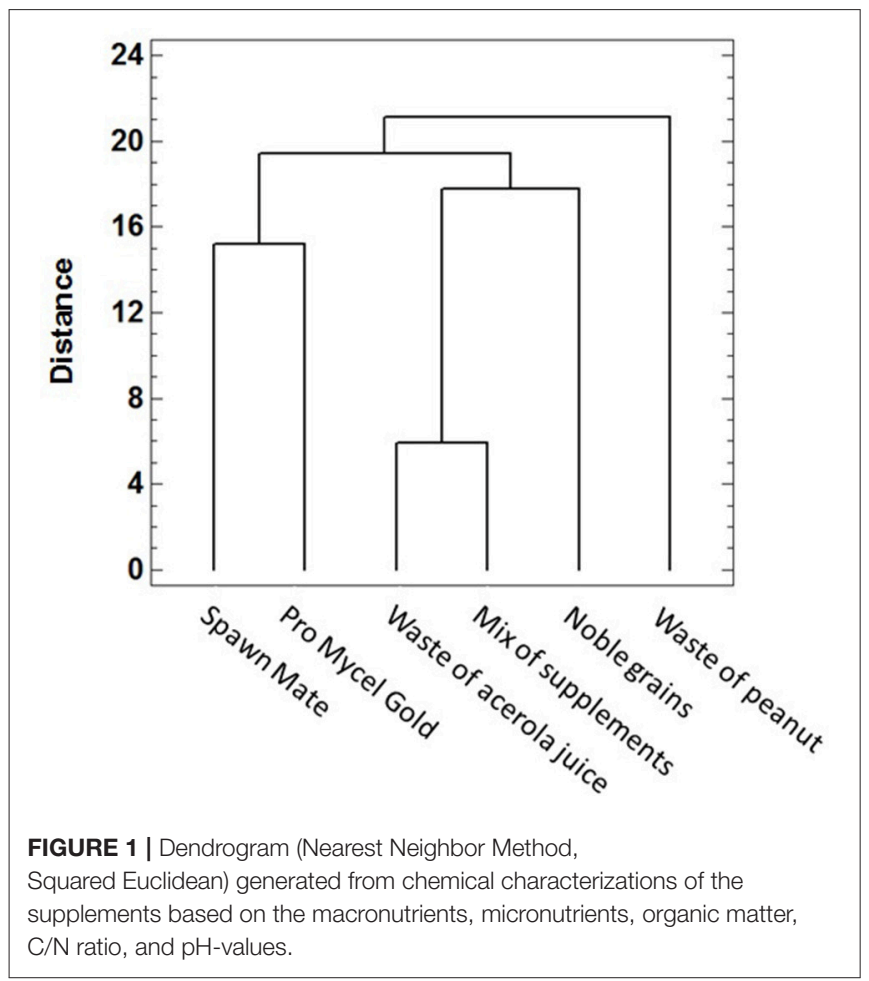

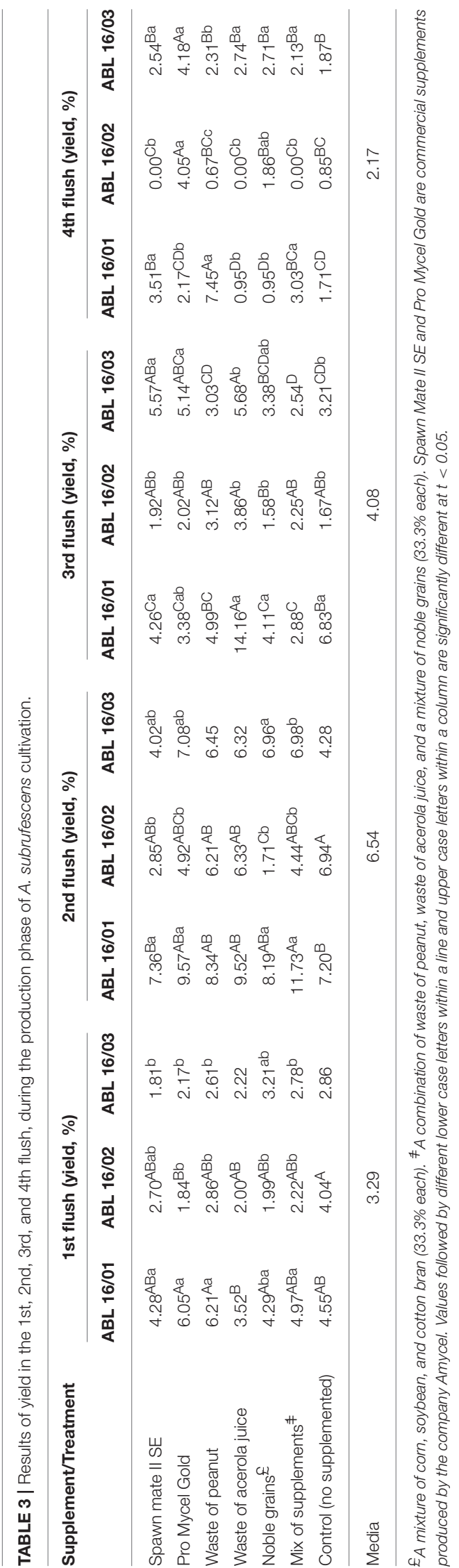


TABLE 4 | Results of total yield, number, and weight of mushroom, during the production phase of $A$. subrufescens cultivation.

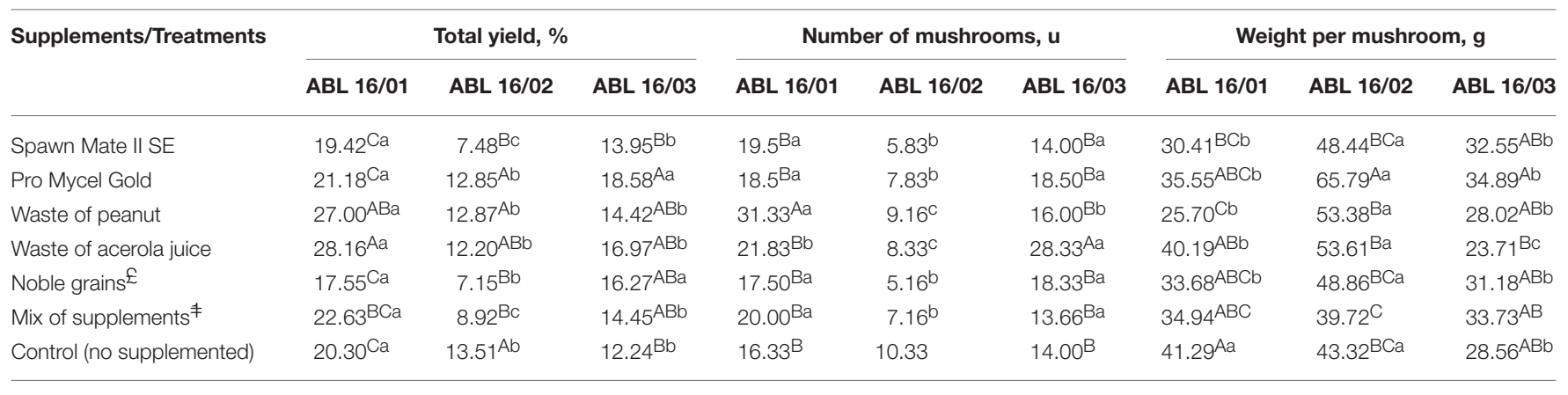

Media

16.10

15.34

38.45

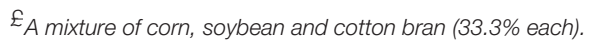

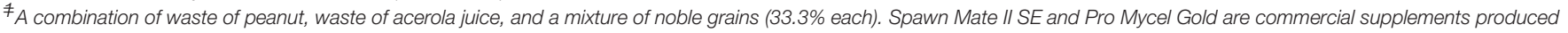
by the company Amycel. Values followed by different lower case letters within a line and upper case letters within a column are significantly different at $t<0.05$.

yield values in each flush (1st, 2nd, 3rd, and 4th) with the other strains. In the substrate control, there was no significant difference among yield values in each flush by the strains, except the third flush (Table 3).

Considering the 1st flush, the Pro Mycel Gold and peanut waste supplements provided the highest yields with ABL 16/01 strain. The substrate control provided the highest yield with ABL 16/02 strain, and ABL 16/03 strain showed no response to substrate supplementation. Although ABL 16/03 strain did not show a significant difference due to the supplementation, it was verified that $\mathrm{Ca}$ contents $\left(21-25 \mathrm{~g} \mathrm{~kg}^{-1}\right)$ and $\mathrm{B}$ content $\left(23-26 \mathrm{mg} \mathrm{kg}^{-1}\right)$ of the supplements positively and negatively influenced the yield values during the 1st flush (Table 5).

In the 2nd flush, the mix of supplement provided the highest yield with ABL 16/01. Once again, the substrate control provided the highest yield with ABL 02/16 strain, and ABL 16/03 strain showed no response to supplementation. Negative correlations were observed between the $\mathrm{P}\left(3.4-5.3 \mathrm{~g} \mathrm{~kg}^{-1}\right), \mathrm{K}\left(14-17 \mathrm{~g} \mathrm{~kg}^{-1}\right)$, $\mathrm{Mg}\left(1.9-3.2 \mathrm{~g} \mathrm{~kg}^{-1}\right)$, and $\mathrm{B}\left(26 \mathrm{mg} \mathrm{kg}^{-1}\right)$ contents in the 2nd flush for ABL 16/02 and ABL 16/03 strains. The ABL 16/03 strain seems to be sensitive to the $\mathrm{B}$ contents of the supplements.

In the 3rd flush a particular results with the acerola juice waste provided the highest yield, significantly higher than control substrate in the three strains studied (Table 3), which may indicate a slow release of nutrients from this supplement to the mushroom, although correlation was not observed between any strains, chemical characteristics and 3rd flush (Table 5).

It is important to emphasize the influence of supplementation in the last flush (4th), to all stains used, when compared with the control. Some chemical characteristics may explain the positive contribution of the supplements in the high yield obtained: (i) the amount of $\mathrm{Cu}$ (close to $15 \mathrm{mg} \mathrm{kg}^{-1}$ ), Fe (close to $795 \mathrm{mg} \mathrm{kg}^{-1}$ ), and $\mathrm{Mn}$ (close to $52 \mathrm{mg} \mathrm{kg}^{-1}$ ) for the ABL 16/01 strain; and (ii) the amount of S (close to $2.8 \mathrm{mg} \mathrm{kg}^{-1}$ ) for the ABL 16/02 and the ABL 16/03 strain (Tables 2, 3).

The only strain that did not respond to supplementation in the total yield was the ABL 16/02, for which superior yield was observed with the substrate control (Table 4). The addition of acerola juice waste to the substrate cultivated with the $\mathrm{ABL}$
$16 / 01$ strain resulted in a significant superior total yield due to the low $\mathrm{P}\left(1.8 \mathrm{~g} \mathrm{~kg}^{-1}\right), \mathrm{K}\left(9 \mathrm{~g} \mathrm{~kg}^{-1}\right)$, and $\mathrm{Mg}\left(1.7 \mathrm{~g} \mathrm{~kg}^{-1}\right)$ contents, which directly negatively influences the number of mushrooms harvested (Table 5). The high values of the $\mathrm{C} / \mathrm{N}$ ratio (26) provided an increase in the total yield for ABL 16/01 strain. The amount of $\mathrm{Cu}$ and $\mathrm{Mn}$ provided a positive correlation with the number of mushrooms for the ABL 16/01 strain. Finally, the ABL 16/03 strain responded to the addition of supplements with high $\mathrm{N}$ content, providing significant superior yield.

Although correlation found among the chemical characteristics of the substrates and the weight of the mushrooms, ABL 16/02 strain provided mushrooms with high mushroom weight, as well as Pro Mycel Gold ones (Table 4).

\section{DISCUSSION}

The supplementation of the compost or substrate at spawning is an important and necessary practice used in A. bisporus and P. ostreatus cultivation to improve the quality of the mushroom and the efficiency of the crop during commercial production. Although supplements are not marketed around the world for the commercial production of A. subrufescens, upgrading the productive process can make a difference for the development of this important medicinal species.

Commercial supplements are marketed in different countries with a high potential for mushroom industry. Currently, the countries with higher mushroom production are China, USA, Poland, Netherlands, India, France, Spain, Canada, Mexico, and others (Royse et al., 2017). Some of these countries, like China and India, do not have companies that commercialize supplements to be applied in the substrate for mushroom production. In addition to these large mushroom-producing countries, other countries also produce mushrooms with a regular production scale, such as Brazil, Argentina, South Africa, Iran, Thailand, Vietnam, etc. Therefore, in our understanding, the practice of supplementation can also be performed in 
TABLE 5 | Correlations between chemical characteristics of the supplements and the production parameters of the mushroom cultivation.

\begin{tabular}{|c|c|c|c|}
\hline \multirow{3}{*}{$\begin{array}{l}\text { Person } \\
\text { Correlation } \\
\text { Chemical } \\
\text { characteristics }\end{array}$} & \multicolumn{3}{|c|}{ Production parameters } \\
\hline & \multicolumn{3}{|c|}{ ABL $16 / 01$} \\
\hline & 4th flush & Total yield & $\begin{array}{l}\text { Number of } \\
\text { mushroom }\end{array}$ \\
\hline \multirow[t]{2}{*}{ P } & - & -0.8925 & -0.8492 \\
\hline & & 0.0167 & 0.0324 \\
\hline \multirow[t]{2}{*}{ K } & - & -0.9042 & -0.8694 \\
\hline & & 0.0133 & 0.0245 \\
\hline \multirow[t]{2}{*}{ Mg } & - & -0.8577 & - \\
\hline & & 0.0291 & \\
\hline \multirow[t]{2}{*}{$\mathrm{Cu}$} & 0.8345 & - & 0.9204 \\
\hline & 0.0388 & & 0.0093 \\
\hline \multirow[t]{2}{*}{$\mathrm{Fe}$} & 0.8698 & - & 0.9762 \\
\hline & 0.0243 & & 0.0008 \\
\hline \multirow[t]{2}{*}{$\mathrm{Mn}$} & 0.8839 & - & - \\
\hline & 0.0194 & & \\
\hline \multirow[t]{2}{*}{$\mathrm{C} / \mathrm{N}$} & - & 0.8138 & - \\
\hline & & 0.0482 & \\
\hline
\end{tabular}

\begin{tabular}{lccc}
\hline \multirow{2}{*}{$\begin{array}{l}\text { Chemical } \\
\text { characteristics }\end{array}$} & \multicolumn{3}{c}{ ABL 16/02 } \\
\cline { 2 - 4 } & 2nd flush & 4th flush & Number of mushroom \\
\hline $\mathrm{P}$ & -0.8445 & - & -0.8405 \\
& 0.0344 & - & 0.0362 \\
$\mathrm{~K}$ & -0.8577 & - & -0.8895 \\
& 0.0289 & & 0.0176 \\
$\mathrm{Mg}$ & -0.9406 & -0.9444 \\
& 0.0052 & 0.9256 & - \\
$\mathrm{S}$ & - & 0.0081 & - \\
& & & \\
\end{tabular}

\begin{tabular}{lcccc}
\hline Chemical characteristics & \multicolumn{4}{c}{ ABL 16/03 } \\
\cline { 2 - 4 } & 1st flush & 2nd flush & 4th flush & Total yield \\
\hline $\mathrm{N}$ & - & - & - & 0.8188 \\
& & & & 0.0463 \\
$\mathrm{Ca}$ & 0.8211 & - & - & \\
& 0.0452 & & & - \\
$\mathrm{S}$ & - & - & 0.9640 & - \\
& & & 0.0019 & - \\
$\mathrm{B}$ & -0.8257 & -0.9616 & - & \\
\hline
\end{tabular}

First data correspond to $r$-values (degree of significance) and second data correspond to the P-values (probability). Values in bold mean: $r$-values above \pm 0.7 and P-values below 0.05 .

these countries using agricultural wastes or even noble grain meal.

In our literature review, two reports were found that utilized practice of substrate supplementation in the production of $A$. subrufescens (Kopytowski Filho et al., 2008; Dias et al., 2014). These studies had positive and negative results regarding the practice of supplementation. In both reports, the authors did not verify the influence of chemical characteristics of the supplements as a function of the physiological development of the mushrooms (1st, 2nd, 3rd, 4th, total yield, number, and weight of mushroom), beside, they did not use three different strains.

The present research confirms the importance of the supplementation practice, not just with commercial supplements but also with supplements based on agricultural wastes (peanut and acerola juice). The supplements based on noble grains may be used in some countries and have very similar chemical characterizations to the commercial supplements (Figure 1). The use of an appropriated strain is fundamental to supplementation practice. Subsequently, several companies that market supplements also market strains (i.e., Amycel and Lambert), providing greater safety in the production process.

The addition of acerola juice waste with the ABL 16/01 strain improved the total yield $\sim 39 \%$, and the addition of Pro Mycel Gold in the ABL 16/03 strain improved yield $\sim 51 \%$ relative to the unsupplemented compost.

Due to the use of six different sources of organic supplements and three commercially grown strains in Brazil, it was possible to find some correlations that may be useful for the formulation or use of a waste as a substrate supplement to produce $A$. subrufescens. The most important elements that were verified in the two strains (ABL 16/01 and ABL 16/02) are $\mathrm{P}, \mathrm{K}$, and $\mathrm{Mg}$, whose contents above $3.4,14$, and $1.9 \mathrm{~g} \mathrm{~kg}^{-1}$ can reduce the yield of the mushrooms (in the flush analyzed separately or in total yield). Sinden in 1949 already warned the mushroom producers about the problem of $\mathrm{Mg}$ toxicity, at this time the approach was carried out in the correction of the casing layer $\mathrm{pH}$ using dolomitic limestone for A. bisporus cultivation (Atkins, 1974). Later Zied et al. (2012) verified the same negative effect of $\mathrm{Mg}$ using dolomitic limestone in A. subrufescens cultivation.

$S$ content was also verified as an important macronutrient in two strains (ABL 16/02 and ABL 16/03) in the 4th flush, whose content close to $2.8 \mathrm{~g} \mathrm{~kg}^{-1}$ provided high yield (Tables 2, 3). The use of $\mathrm{S}$ in the form of calcium sulfate $\left(\mathrm{CaSO}_{4}\right)$ is well-documented in the cultivation of mushrooms, being added as an ingredient in the preparation of substrate of the species Pleurotus spp., Lentunula edodes, A. bisporus in different amounts for improving the physical characteristics of the substrate and provide $\mathrm{Ca}$ and $\mathrm{S}$ for mushroom nutrition (Liyama et al., 1994; Curvetto et al., 2002; Mandeel et al., 2005; Uddin et al., 2013). The macronutrient values found in the correlation can be used as reference for future studies involving dose response of an element and yield of mushroom, i.e., increasing doses of $\mathrm{S}$ in the substrate $(2.0,2.4,2.8,3.2$, $3.6 \mathrm{~g} \mathrm{~kg}^{-1}$ ).

The $\mathrm{B}$ content also reduced the harvest in the 1 st and 2 nd flush in the ABL 03/16 strain. $\mathrm{Ca}, \mathrm{S}, \mathrm{Cu}, \mathrm{Fe}$, and $\mathrm{Mn}$ were found to contribute positively to the physiological development of the mushroom. Estrada Rodrigues and Royse (2007) also verified the positive effect of these micronutrients $(\mathrm{Mn}$ and $\mathrm{Cu}$ ) when applied to the substrate on the yield of Pleurotus eryngii.

The $\mathrm{N}$ content and the $\mathrm{C} / \mathrm{N}$ ratio provided different reactions depending on the strain used (Table 5). Some studies reported the influence of the $\mathrm{N}$ content and the $\mathrm{C} / \mathrm{N}$ ratio in the 
production of the compost for A. subrufescens production (Zied and Minhoni, 2012; Llarena-Hernández et al., 2014; PardoGiménez et al., 2014). In Brazil, the compost used for $A$. subrufescens production has a $\mathrm{C} / \mathrm{N}$ ratio close to $27 / 1$ (at the end of Phase II), and in Europe, the compost has a $\mathrm{C} / \mathrm{N}$ ratio close to 18/1 (at the end of Phase II) (Andrade et al., 2007; Siqueira et al., 2011; Zied et al., 2011b; Llarena-Hernández et al., 2013, 2014).

The difference in the $\mathrm{C} / \mathrm{N}$ ratio used in the different continents is related to the method of preparation of the compost (formulation, Phase I, and Phase II). In Europe, the compost used in the production of $A$. subrufescens is the same as the compost prepared to A. bisporus production, and in Brazil, a poorer compost with a higher $\mathrm{C} / \mathrm{N}$ ratio is used specifically for $A$. subrufescens production. In this sense, we can consider not only the method of preparation of the compost but also the nutritional and specific demand of the macro and micronutrient of the strain used. There are strains more demanding in $\mathrm{N}$ content and others in $\mathrm{C}$ content.

Finally, the composting method used to produce $A$. subrufescens is still not ideal, despite advances and the publication of new information. It is not even possible to obtain the highest yield in the first flush of the harvest. In the present manuscript, the highest yields were obtained in the 2 nd (media of $6.54 \%$ ) and 3 rd flushes (media of $4.08 \%$ ) (Table 3). Other authors have also verified the low yield in the 1st flush and the long cycle of crop (Zied and Minhoni, 2009; Colauto et al., 2011; Zied et al., 2011b; Pardo-Giménez et al., 2014; Martos et al., 2017).

\section{CONCLUSION}

The practice of supplementation is an important tool for improving yield in the industrial production of A. subrufescens.

\section{REFERENCES}

Andrade, M. C. N., Kopytowski Filho, J., Minhoni, M. T. A., Coutinho, L. N., and Figueiredo, M. B. (2007). Productivity, biological efficiency, and number of Agaricus blazei mushrooms grown in compost in the presence of Trichoderma sp. and Chaetomium olivacearum contaminants. Braz. J. Microbiol. 38, 243-247. doi: 10.1590/S1517-838220070002 00010

Atkins, F. C. (1974). Guide to Growing Mushrooms. London: Faber and Faber.

Bell, D. T., and Ward, S. C. (1984). Foliar and twig macronutrients $(\mathrm{N}, \mathrm{P}, \mathrm{K}, \mathrm{Ca}$ and $\mathrm{Mg}$ ) in selected species of Eucalyptus used in rehabilitation: sources of variation. Plant Soil 81, 363-376. doi: 10.1007/BF023 23051

Carvalho Sousa, M. A., Zied, D. C., Marques, S. C., Rinker, D. L., Alm, G., and Dias, E. S. (2016). Yield and enzyme activity of different strains of almond mushroom in two cultivation systems. Sydowia 68, 35-40. doi: 10.12905/0380.sydowia68-2016-0035

Colauto, N. B., Silveira, A. R., Eira, A. F., and Linde, G. A. (2011). Pasteurization of brazilian peat for Agaricus brasiliensis cultivation. Semin. Ciênc. Agrár. 31, 1331-1336. doi: 10.5433/1679-0359.2010v31n4Sup1 p1331

Curvetto, N., Figlas, D., and Delmastro, S. (2002). Sunflower seed hulls as substrate for the cultivation of shiitake mushrooms. HortTechnology 12, 652-655.

Dias, E. S., Zied, D. C., Alm, G., and Rinker, D. L. (2014). Supplementation of compost for Agaricus subrufescens cultivation. Ind. Biotechnol. 10, 130-132. doi: 10.1089/ind.2013.0040
Waste materials and noble grains can be selected as quality supplements. The use of appropriated strains is essential to the success of the practice of supplementation. We suggest that materials with high $\mathrm{Mg}$ content should be avoided on the selection of an ideal supplement, while materials with high S, Cu, and $\mathrm{Mn}$ contents should be selected as ideal supplements. Therefore, other studies should be performed to better understand this relationship in an experimental crop, to know, with safety, which macro and micronutrients should be present in a commercial supplement to be used in large scale by the mushroom industry.

\section{AUTHOR CONTRIBUTIONS}

$\mathrm{DZ}$ assisted in the experimental design, supervised the execution and the interpretation of the data, CC and MZ carried out the experiments, JP analyzed the results, ED and AP-G coordinated the statistical and wrote the manuscript. All authors read and approved the final manuscript.

\section{FUNDING}

This research was supported financially by Fundação de Amparo a Pesquisa do Estado de São Paulo (FAPESP 15/15306-3 and 15/24788-1).

\section{ACKNOWLEDGMENTS}

The authors are grateful to Centro de Estudos de Cogumelos (CECOG) and the Universidade Estadual Paulista (UNESP) for providing an adequate support for conducting the study and for Funghi \& Flora company for providing the commercial strains.

Dias, E. S., Zied, D. C., and Rinker, D. L. (2013). Physiologic response of Agaricus subrufescens using different casing materials and practices applied in the cultivation of Agaricus bisporus. Fungal. Biol. 117, 569-575. doi: 10.1016/j.funbio.2013.06.007

Estrada Rodrigues, A., , and Royse, D. J. (2007). Yield, size and bacterial blotch resistance of Pleurotus eryngii grown on cottonseed hulls/oak sawdust supplemented with manganese, copper and whole ground soybean. Bioresour. Technol. 98, 1898-1906. doi: 10.1016/j.biortech.2006.07.027

Farnet, A. M., Qasemian, L., Peter-Valence, F., Ruaudel, F., Savoie, J. M., Roussos, S., et al. (2014). Do spawn storage conditions influence the colonization capacity of a wheat-straw-based substrate by Agaricus subrufescens? C. R. Biol. 337, 443-450. doi: 10.1016/j.crvi.2014.06.002

Horm, V., and Ohga, S. (2008). Potential of compost with some added supplementary materials on the development of Agaricus blazei Murill. J. Fac. Agr. Kyushu Univ. 53, 417-422.

Kopytowski Filho, J., Minhoni, M. T. A., Andrade, M. C. N., and Zied, D. C. (2008). Effect of compost supplementation (soybean meal and Champfood) at different phases (spawning and before casing) on productivity of Agaricus blazei ss. Heinemann (A. brasiliensis). Mush. Sci. 17, 260-270.

Liyama, K., Stone, B. A., and Macauley, B. J. (1994). Compositional changes in compost during composting and growth of Agaricus bisporus. Appl. Environ. Microbiol. 60, 1538-1546.

Llarena-Hernández, C. R., Largeteau, M. L., Ferrer, N., Regnault-Roger, C., and Savoie, J. M. (2014). Optimization of the cultivation conditions for mushroom production with European wild strains of Agaricus subrufescens and Brazilian cultivars. J. Sci. Food Agric. 94, 77-84. doi: 10.1002/jsfa.6200 
Llarena-Hernández, R. C., Largeteau, M. L., Farnet, A. M., Foulongne-Oriol, M., Ferrer, N., Regnault-Roger, C., et al. (2013). Potential of European wild strains of Agaricus subrufescens for productivity and quality on wheat straw based compost. World J. Microbiol. Biotechnol. 29, 1243-1253. doi: 10.1007/s11274-013-1287-3

Mandeel, Q. A., Al-Laith, A. A., and Mohamed, S. A. (2005). Cultivation of oyster mushrooms (Pleurotus spp.) on various lignocellulosic wastes. World J. Microbiol. Biotechnol. 21, 601-607. doi: 10.1007/s11274-004-3494-4

Martos, E. T., Zied, D. C., Junqueira, P. P. G., Rinker, D. L., Silva, R., Toledo, R. C. C., et al. (2017). Casing layer and effect of primordia induction in the production of Agaricus subrufescens mushroom. Agr. Nat. Resour. 51, 231-234. doi: $10.1016 /$ j.anres.2017.04.003

Matute, R. G., Figlas, D., and Curvetto, N. (2010). Sunflower seed hull based compost for Agaricus blazei Murill cultivation. Int. Biodeterior. Biodegrad. 64, 742-747. doi: 10.1016/j.ibiod.2010.08.008

Nakanishi, A. B., Soares, A. A., Natali, M. R., Comar, J. F., Peralta, R. M., and Bracht, A. (2014). Effects of the continuous administration of an Agaricus blazei extract to rats on oxidative parameters of the brain and liver during aging. Molecules 19, 18590-18603. doi: 10.3390/molecules191118590

Pardo-Giménez, A., Catalán, L., Carrasco, J., Álvarez-Ort,í, M., Zied, D. C., and Pardo, J. E. (2016). Effect of supplementing crop substrate with defatted pistachio meal on Agaricus bisporus and Pleurotus ostreatus production. J. Sci. Food Agr. 96, 3838-3845. doi: 10.1002/jsfa.7579

Pardo-Giménez, A., González, J. E. P., Figueirêdo, V. R., and Zied, D. C. (2014). Adaptabilidad de cepas brasileñas de Agaricus subrufescens Peck a la fructificación sobre diferentes capas de cobertura en cultivo comercial. Rev. Iberoam. Micol. 31, 125-130. doi: 10.1016/j.riam.2013.05.002

Pardo-Giménez, A., Zied, D. C., Álvarez-Ort,í, M., Rubio, M., and Pardo, J. E. (2012). Effect of supplementing compost with grapeseed meal on Agaricus bisporus production. J. Sci. Food Agr. 92, 1665-1671. doi: 10.1002/jsfa.5529

Royse, D. J., Baars, J., and Tan, Q. (2017). "Current overview of mushroom production in the world," in Edible and Medicinal Mushrooms: Technology and Applications, eds D. C. Zied and A. Pardo-Giménez (West Sussex: WileyBlackwell), 5-13.

Siqueira, F. G., Martos, E. T., Silva, E. G. D., Silva, R. D., and Dias, E. S. (2011). Biological efficiency of Agaricus brasiliensis cultivated in compost with nitrogen concentrations. Hortic. Bras. 29, 157-161. doi: $10.1590 /$ S0102-05362011000200004

Sonneveld, C., and van Elderen, C. W. (1994). Chemical analysis of peaty growing media by means of water extraction. Commun. Soil Sci. Plant Anal. 25, 3199-3208. doi: 10.1080/00103629409369258

Souza, T. P., Marques, S. C., Santos, D. M. D. S., and Dias, E. S. (2014). Analysis of thermophilic fungal populations during phase II of composting for the cultivation of Agaricus subrufescens. World J. Microbiol. Biotechnol. 30, 2419-2425. doi: 10.1007/s11274-014-1667-3

Uddin, M. J., Haque, S., Haque, M. E., Bilkis, S., and Biswas, A. K. (2013). Effect of different substrate on growth and yield of button mushroom. J. Environ. Sci. Nat. Res. 5, 177-180. doi: 10.3329/jesnr.v5i2.14810

Venkateshgobi, V., Rajasankar, S., Johnson, W. M. S., Prabu, K., and Ramkumar, M. (2018). Neuroprotective effect of Agaricus blazei extract against rotenone-induced motor and nonmotor symptoms in experimental model of Parkinson's disease. Int. J. Nutr. Pharmacol. Neurol. Dis. 8, 59-65. doi: 10.4103/ijnpnd.ijnpnd_20_18

Venkatesh Gobi, V., Rajasankar, S., Ramkumar, M., Dhanalakshmi, C., Manivasagam, T., Justin Thenmozhi, A., et al. (2017). Agaricus blazei extract abrogates rotenone-induced dopamine depletion and motor deficits by its anti-oxidative and anti-inflammatory properties in Parkinsonic mice. Nutr. Neurosci. 19,1-10. doi: 10.1080/1028415X.2017.1337290
Venkatesh Gobi, V., Rajasankar, S., Ramkumar, M., Dhanalakshmi, C., Manivasagam, T., Justin Thenmozhi, A., et al. (2018). Agaricus blazei extract attenuates rotenone-induced apoptosis through its mitochondrial protective and antioxidant properties in SH-SY5Y neuroblastoma cells. Nutr. Neurosci. 21, 97-107. doi: 10.1080/1028415X.2016.1222332

Wang, H., Fu, Z., and Han, C. (2013). The medicinal values of culinary-medicinal royal sun mushroom (Agaricus blazei Murrill). Evid. Based Complement Altern. Med. 8, 59-65. doi: 10.1155/2013/842619

Wang, J. T., Wang, Q., and Han, J.R. (2013). Yield, polysaccharides content and antioxidant properties of the mushroom Agaricus subrufescens produced on different substrates based on selected agricultural wastes. Sci. Hortic. 157, 84-89. doi: 10.1016/j.scienta.2013.04.006

Zied, D. C., and Minhoni, M. D. A. (2009). Influence of the environment of production in yield of mushroom Agaricus blazei ss. Heinemann (A. brasiliensis). Energ. Agric. 24, 17-34.

Zied, D. C., and Minhoni, M. T. A. (2012). Indoor composting methods for growing Agaricus subrufescens and the chemical characteristics of basidiomata. Energ. Agric. 27, 45-59. doi: 10.17224/EnergAgric.2012v27n4p45-59

Zied, D. C., Minhoni, M. T.A., Kopytowski-Filho, J., and Andrade, M. C. N. (2010). Production of Agaricus blazei ss. Heinemann (A. brasiliensis) on different casing layers and environments. World J. Microbiol. Biotechnol. 26, 1857-1863. doi: 10.1007/s11274-010-0367-x

Zied, D. C., Minhoni, M. T. A., Kopytowski-Filho, J., Barbosa, L., and Andrade, M. C. N. (2011a). Medicinal mushroom growth as affected by non-axenic casing soil. Pedosphere 21, 146-153. doi: 10.1016/S1002-0160(11)60112-4

Zied, D. C., Pardo-Gimenez, A., Savoie, J.M., Pardo, J.E., and Callac, P. (2011b). "“Indoor" method of composting and genetic breeding of the strains to improve yield and quality of the almond mushroom Agaricus subrufescens," in 7th International Conference on Mushroom Biology and Mushroom Products (Arcachon, INRA), 424-432.

Zied, D. C., Pardo, J. E., Thomaz, R. S., Miasaki, C. T., and Pardo-Gimenez, A. (2017). Mycochemical characterization of Agaricus subrufescens considering their morphological and physiological stage of maturity on the traceability process. Biomed. Res. Int. 2017:2713742. doi: 10.1155/2017/2713742

Zied, D. C., Pardo-Giménez, A., de Almeida Minhoni, M. T., Boas, R. V., AlvarezOrti, M., and Pardo-González, J. E. (2012). Characterization, feasibility and optimization of Agaricus subrufescens growth based on chemical elements on casing layer. Saudi J. Biol. Sci. 19, 343-347. doi: 10.1016/j.sjbs.2012.04.002

Zied, D. C., Pardo-Gimenez, A., Pardo, J. E., Dias, E. S., Carvalho, M. A., and Minhoni, M. T. A. (2014a). Effect of cultivation practices on the $\beta$-glucan content of Agaricus subrufescens basidiocarps. J. Agric. Food Chem. 62, 41-49. doi: $10.1021 / \mathrm{jf} 403584 \mathrm{~g}$

Zied, D. C., Penachio, S. M., Dias, E. S., Minhoni, M. T. A., Ferraz, R. A., and Vieites, R. L. (2014b). Influence of productivity and processing method on physicochemical characteristics of white button mushrooms in Brazil. J. Sci. Food Agr. 94, 2850-2855. doi: 10.1002/jsfa.6624

Conflict of Interest Statement: The authors declare that the research was conducted in the absence of any commercial or financial relationships that could be construed as a potential conflict of interest.

Copyright $\odot 2018$ Zied, Caitano, Pardo-Gimenez, Dias, Zeraik and Pardo. This is an open-access article distributed under the terms of the Creative Commons Attribution License (CC BY). The use, distribution or reproduction in other forums is permitted, provided the original author(s) and the copyright owner are credited and that the original publication in this journal is cited, in accordance with accepted academic practice. No use, distribution or reproduction is permitted which does not comply with these terms. 